\begin{tabular}{|c|c|c|c|c|c|}
\hline JRL & Vol. 12 & No. 1 & Hal : 82 - 88 & $\begin{array}{c}\text { Jakarta, } \\
\text { Juni } 2019\end{array}$ & $\begin{array}{c}\text { p-ISSN : 2085.38616 } \\
\text { e-ISSN : 2580-0442 }\end{array}$ \\
\hline
\end{tabular}

\title{
ANALISIS KADAR NITRIT, NITRAT, DAN FOSFAT BERDASARKAN VARIASI JARAK PENGUKURAN SAMPEL PADA PULAU APUNG DENGAN RUMPUT VETIVER
}

\author{
ANIES MA'RUFATIN, DIAN P. DEWANTI \\ Pusat Teknologi Lingkungan, Badan Pengkajian dan Penerapan Teknologi (BPPT) \\ Gedung Geostech 820 Lantai 3, Kawasan Puspiptek, Tangerang Selatan \\ Email: anies.marufatin@bppt.go.id
}

\begin{abstract}
Abstrak
Kualitas air sungai harus tetap dijaga dari pencemaran dengan pengelolaan dan pengendalian yang bijak. Beberapa zat pencemar di sungai yang harus dikendalikan adalah nitrit, nitrat dan fosfat. Jumlah nitrit, nitrat, dan fosfat yang berlebihan akan merugikan karena berpengaruh terhadap kesehatan dan biodiversitas ekosistem perairan tersebut. Salah satu upaya pengendalian pencemaran zat pecemar tersebut adalah fitoremediasi menggunakan rumput vetiver dengan sistem pulau apung. Vetiver ditumbuhkan pada tiga pulau apung yang berbentuk persegi panjang dengan panjang masing-masing 4,5 m. Pulau apung ditempatkan pada badan sungai. Akar vetiver yang tumbuh dibawah permukaan air sungai akan menyerap berbagai bahan pencemar. Pengambilan sampel air dilakukan pada ketiga ujung awal dan akhir pulau apung (inflow dan outflow) untuk mengetahui perubahan kadar nitrit, nitrat, dan fosfat yang dipengaruhi oleh akar vetiver. Jarak pengambilan sampel adalah 4,5 m, $9 \mathrm{~m}$, dan 13,5 m. Pulau apung dengan rumput vetiver yang diujicoba mampu menurunkan jumlah nitrit, nitrat dan fosfat. Penurunan optimum terjadi pada nitrat yang mencapai $18 \%$ dengan jarak pengambilan sampel pulau apung 9 meter. Tiga jarak pengambilan sampel awal dan akhir pulau apung yang berbeda efektif untuk menurunkan fosfat.
\end{abstract}

Kata kunci: nitrit, nitrat, fosfat, pulau apung, rumput vetiver

\section{ANALYSIS OF NITRITE, NITRATE AND PHOSPHATE BASED ON VARIATIONS OF SAMPLING DISTANCE MEASUREMENT}

\begin{abstract}
River water quality should be protected from pollution through management and control properly. Some pollutants in the river that must be controlled are nitrites, nitrates and phosphate. Excessive amounts of nitrite, nitrate and phosphate will be detrimental because they affect the health and biodiversity of these aquatic ecosystems. One of the efforts to control pollution of pollutants is phytoremediation using vetiver grass with a floating island system. Vetiver is grown on three floating islands which are rectangular with a length of $4.5 \mathrm{~m}$ each. Floating island is placed on the river body. Vetiver root that grows below the surface of the river will absorb various pollutants. Sampling of water was carried out at the three ends of the beginning and end of the floating island (inflow and outflow) to determine the changes in the levels of nitrite, nitrate, and phosphate which are affected by vetiver roots. The sampling distance were $4.5 \mathrm{~m}, 9 \mathrm{~m}$, and $13.5 \mathrm{~m}$. Floating island with vetiver grass tested can reduce the amount of nitrite, nitrate and phosphate. The optimum decrease occurred in nitrates which reached 18\% with the sampling distance of floating islands 9 meters. Three different distances of floating islands are effective to reduce phosphate.
\end{abstract}

Keywords: nitrite, nitrate, phosphate, floating island, vetiver grass 


\section{PENDAHULUAN}

Sungai di Indonesia, khususnya di kota besar mengalami pencemaran lingkungan semakin kompleks dan sulit dikendalikan. Fasilitas pengolahan air limbah domestik yang kurang, mengakibatkan tercemarnya badan sungai oleh air limbah domestik, bahkan badan sungai yang diperuntukkan sebagai bahan baku air minum pun telah tercemar.

Untuk wilayah Jakarta, air limbah domestik memberikan kontribusi terhadap pencemaran air sekitar 75\%, air limbah perkantoran dan daerah komersial 15\% dan air limbah industri 10\% ${ }^{1)}$. Beban polutan organik, air limbah rumah tangga sekitar $70 \%$, air limbah perkantoran 14\%, dan air limbah industri memberikan kontribusi $16 \%{ }^{1)}$. Dengan demikian, air limbah rumah tangga dan air limbah perkantoran adalah penyumbang terbesar terhadap pencemaran air di wilayah DKI Jakarta. Selain itu, berkembangnya lokasi pemukiman di daerah penyangga yang ada disekitar Jakarta, tanpa dilengkapi dengan fasilitas pengolahan air limbah sehingga seluruh limbah dibuang ke saluran umum juga turut menambah pencemaran air ${ }^{1)}$.

Kualitas air sungai perlu dijaga agar tetap pada kondisi alamiahnya dengan dilakukan pengolahan dan pengendalian pencemaran air secara bijaksana. Dalam Peraturan Pemerintah No. 82 Tahun 2001 menyebutkan definisi pengendalian pencemaran air yaitu upaya pencegahan dan penanggulangan pencemaran air serta pemulihan kualitas air untuk menjamin kualitas air agar sesuai dengan baku mutu air.

Parameter yang digunakan untuk mengukur dan mengetahui kualitas air yakni meliputi parameter fisika, kimia dan mikrobiologi2). Parameter fisika dapat dilihat dari tingkat kekeruhan warna air sungai, suhu, debit, TDS (Total Disolve Solid) serta TSS (Total Suspended Solid). Untuk parameter kimia meliputi Dissolved Oxygen (DO), Biochemical Oxygen Demand (BOD), Chemical Oxygen Demand (COD), serta $\mathrm{pH}^{3}$ ). Selain itu, termasuk juga dalam parameter kimia kualitas air yaitu nitrit, nitrat, fosfat, NKjedahl, dan kalium. Parameter mikrobiologi dapat diketahui dengan mengambil sampel dan menganalisis mikroorganisme apa saja yang hidup didalamnya.

Adanya zat hara di lingkungan perairan memiliki dampak positif namun jika masih dalam jumlah yang wajar. Akan tetapi, zat-zat tersebut bisa menimbulkan dampak negatifnya terhadap penurunan kandungan oksigen di perairan, penurunan biodiversitas dan terkadang memperbesar potensi muncul dan berkembangnya jenis fitoplankton berbahaya. Zat hara yang umum menjadi fokus perhatian di lingkungan perairan diantaranya nitrit, nitrat, dan fosfat.

Meningkatnya nutrisi dalam air, seperti nitrogen dan fosfat akan meningkatkan siklus hidup alga, cyanobacteria, tanaman air ${ }^{4}$. Zatzat tersebut dalam jumlah yang besar menyebabkan terjadinya ledakan populasi (blooming) alga sangat besar. Tentunya hal ini sangat merugikan karena dapat berpengaruh terhadap kesehatan dan biodiversitas ekosistem perairan setempat ${ }^{5}$. Unsur nitrogen dan fosfat dalam air laut berfungsi sebagai nutrisi bagi biota di dalamnya. Dalam batasbatas konsentrasi tertentu yang layak untuk keperluan biota, maka keberadaan unsurunsur nutrisi tersebut tidak bermasalah, namun bila konsentrasinya berlimpah maka akan menyebabkan terjadinya eutrofikasi yang menyebabkan unsur-unsur nutrisi tersebut berubah fungsinya6).

Fitoremediasi menjadi salah satu solusi untuk mengurangi pencemaran sungai yaitu dengan bantuan tanaman dan bagianbagiannya ${ }^{7}$. Salah satu tanaman yang dapat digunakan untuk mengurangi pencemaran sungai adalah rumput vetiver. Vetiver dalam bahasa latin disebut Vetiveria zizanioides atau Andropogon zizanoides merupakan sejenis rumput yang berasal dari India. Tumbuhan ini banyak tumbuh di Rajasthan, Uttar Pradesh, Punjab dan pantai barat. Di India tumbuhan ini dikenal dengan sebutan khas-khas sedangkan di Indonesia dikenal dengan akar wangi. Tanaman ini termasuk golongan rumput dengan tinggi 0,5-1,5 m. Vetiver dapat tumbuh hampir di semua jenis tanah. Akar wangi tahan terhadap logam berat, salinitas dan dapat tumbuh pada $\mathrm{pH}$ antara $3-11,5$ sehingga dapat digunakan untuk merehabilitasi kondisi fisik 
dan kimia tanah yang rusak $^{8)}$. Vetiver dapat diandalkan untuk konservasi tanah dan air ${ }^{9}$.

Penanaman vetiver dapat dilakukan di media pulau apung (floating island). Floating island dikenal pula sebagai floating treatment wetlands (FTWs) adalah teknologi untuk meningkatkan kualitas air dan membentuk habitat $^{3)}$. Konsep pulau apung sangat sederhana, yakni mengapungkan alat diatas permukaan air untuk dapat digunakan dengan fungsi tertentu. Teknologi sederhana ini dapat diterapkan sebagai media tanam. Dalam hal ini pemanfaatan pulau apung dioptimalkan untuk melakukan remediasi lingkungan khususnya wilayah perairan seperti sungai.

Pulau apung dapat dimanfaatkan sebagai media untuk pengolahan air limbah domestik, pengurangan kadar logam berat, pengolahan air limbah pertanian, membentuk habitat baru, dan sarana wisata ${ }^{10)}$. Pemanfaatan teknologi ini dapat menggabungkan beberapa kepentingan diantaranya sebagai sarana penghijauan, jika menggunakan tanaman yang dapat menyerap polutan maka dapat mengurangi kadar polutan, membentuk habitat baru serta sebagai sarana wisata.

Pulau apung telah dikembangkan pada banyak sistem pengolahan air terbuka. Beberapa kanal, sungai, muara, danau yang tercemar pada negara maju dapat memanfaatkan pulau apung sebagai upaya pengolahan air ${ }^{11)}$. Tanaman yang ditanam pada media pulau apung akan menggantungkan akar tanaman dibawah permukaan air dan menyerap unsur hara dan air. Hal tersebut sama dengan prinsip kerja hidroponik. Pada akar tersebut dapat menciptakan habitat bagi bakteri, alga, zooplankton dan makhluk lainnya. Organisme tersebut bersama dengan akar-akar memainkan peran dalam penyerapan nutrisi dan degradasi racun dalam air ${ }^{11)}$.

Dalam melaksanakan kegiatan ujicoba pulau apung diperlukan tanaman yang ideal untuk fitoremediasi. Tanaman tersebut harus memiliki produktivitas biomassa yang tinggi, harapan hidup pendek dan toleransi yang tinggi terhadap kapasitas akumulasi konsentrasi logam yang tinggi, mudah dikelola dan dapat tumbuh pada berbagai lokasi ${ }^{8}$.
Pemanfaatan tumbuhan untuk remediasi lingkungan sangat ditentukan oleh pemahaman tentang penyerapan logam serta penyerapan dan atau degradasi senyawa organik oleh tumbuhan ${ }^{12)}$.

Kegiatan ini bertujuan untuk menganalisis hasil ujicoba pulau apung dengan rumput vetiver dalam upaya penurunan kadar pencemaran air sungai. Hal ini diharapkan alat yang telah didesain ini mampu menjadi media penanaman vetiver sehingga dapat dimanfaatkan untuk menurunkan kadar pencemaran air sungai yaitu nitrit, nitrat, dan fosfat.

\section{BAHAN DAN METODE}

Penelitian ini merupakan penelitian skala prototipe dan diujicoba di aliran Sungai Kecapi yang merupakan anak Sungai Cisadane. Titik yang diambil terletak di wilayah Kampung Sarimulya, Kelurahan Setu, Kecamatan Setu, Tangerang Selatan. Penelitian dilakukan pada bulan September 2014.

\subsection{Bahan}

Peralatan yang digunakan adalah media tanam vetiver yang dibuat dari potongan pipa dan bambu dengan densitas yang lebih rendah dari air sehingga bisa mengapung. Potongan pipa selanjutnya dirakit sebagai rangka dan bambu yang sudah dibelah sebagai alas yang akan menahan media tanam tanaman vetiver. Rangkaian pipa dan bambu tersebut berbentuk papan persegi panjang menyerupai rakit dengan panjang 4,5 meter dan lebar 1 meter (Gambar 1).

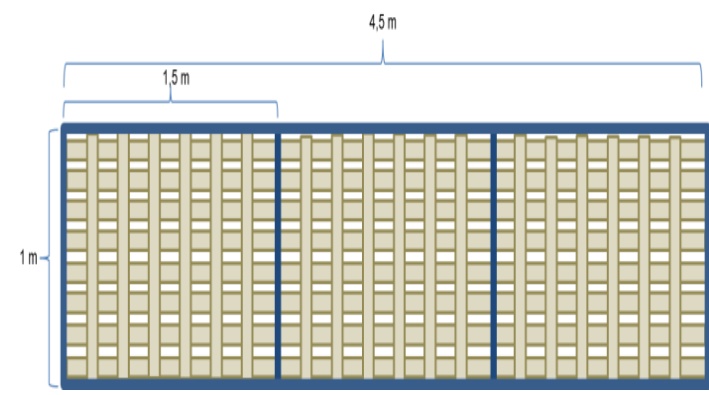


Gambar 1. Ukuran Media Tanam (Pulau

$$
\text { Apung) }
$$

Media tanam vetiver berupa ijuk dari pohon aren yang disebar merata pada permukaan papan. Bibit tanaman vetiver ditanam pada media ijuk dengan jarak antar tanaman sejauh $10 \mathrm{~cm}$ (Gambar 2).

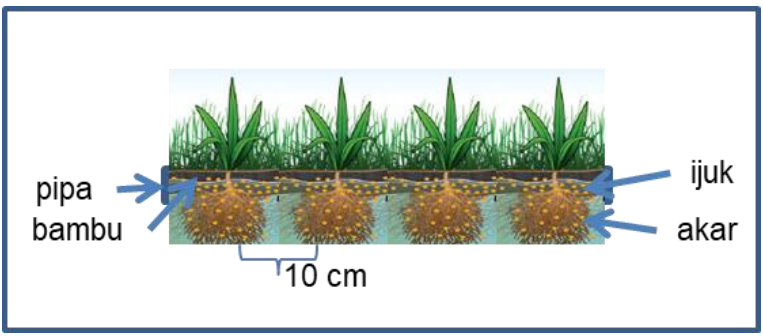

Gambar 2. Jarak Antar Tanaman

\subsection{Metode}

Sebelum dilakukan pengukuran terhadap kemampuan tanaman vetiver dalam menyerap nitrit, nitrat, dan fosfat, terlebih dahulu dilakukan pemasangan rakit yang sudah ditanami tanaman vetiver di tengah aliran sungai dengan posisi memanjang sejajar aliran sungai. Untuk mencegah rakit tersebut hanyut oleh aliran sungai yang deras, maka dipasang tali pada bagian sudut-sudut rakit dan diikat pada pohon-pohon disekitarnya. Pulau apung buatan yang siap untuk dilakukan penanaman rumput vetiver dapat dilihat pada Gambar 3.

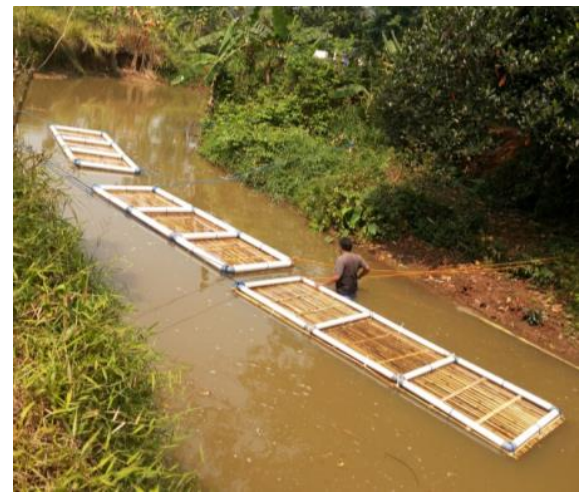

Gambar 3. Media Tanam (Pulau Apung) yang Siap untuk Ditanami Rumput Vetiver
Pada penelitian ini, terdapat empat sampel berdasarkan masing-masing jarak pengukuran yaitu 13,5 meter; 9 meter dan 4,5 meter. Berdasarkan empat data tersebut kemudian dirata-rata untuk mengetahui ratarata kandungan nitrit, nitrat dan fosfat setiap inflow maupun outflow. Berdasarkan sampel yang diambil kemudian dilakukan analisis laboratorium dengan parameter yang didapat yaitu nitrit, nitrat, dan fosfat.

\section{HASIL DAN PEMBAHASAN}

Kegiatan penelitian kualitas air sungai oleh Tim Pusat Teknologi Lingkungan - BPPT pada Sungai Kecapi, anak Sungai Cisadane, Serpong - Tangerang Selatan, telah dilakukan pada selang waktu kurang lebih satu bulan. Teknik penelitian yang dilakukan yaitu dengan menginstal media pulau apung pada sungai tersebut, yang ditanami tanaman vetiver (Gambar 4).

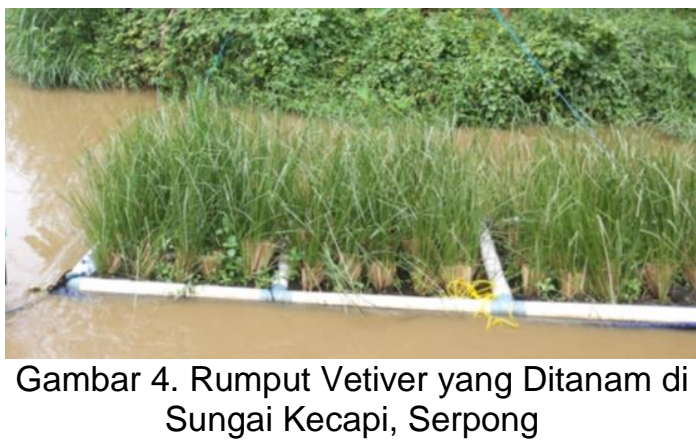

Berdasarkan kriteria mutu air, air sungai tersebut termasuk sungai kelas III, yakni air yang peruntukannya dapat digunakan untuk pembudidayaan ikan air tawar, peternakan, air untuk mengairi pertanaman, dan atau peruntukan lain yang mempersyaratkan mutu air yang sama dengan kegunaan tersebut. Perlakuan yang diberikan yaitu berdasarkan jarak pengambilan sampel awal dan akhir (inflow dan outflow) 13,5 meter; 9 meter dan 4,5 meter.

Berdasarkan Peraturan Pemerintah Republik Indonesia Nomor 82 Tahun 2001 
tentang Pengelolaan Kualitas Air dan Pengendalian Pencemaran Air menyatakan bahwa baku mutu kualitas air sungai kelas III, untuk kadar nitrit yaitu 0,06 mg/L, kadar nitrat $\left(\mathrm{NO}_{3}\right)$ yaitu $20 \mathrm{mg} / \mathrm{L}$, dan kadar total fosfat yaitu
$1 \mathrm{mg} / \mathrm{L}$. Dapat dilihat pada Tabel 1 kadar nitrit melebihi nilai baku mutu, sedangkan nitrat dan fosfat masih dibawah nilai baku mutu.

Tabel 1. Kadar Nitrit, Nitrat, dan Fosfat pada Aliran Sungai Kecapi

\begin{tabular}{|l|c|r|r|r|r|r|r|}
\hline \multirow{2}{*}{ Parameter } & \multirow{2}{*}{ Satuan } & \multicolumn{2}{c|}{$\mathbf{1 3 , 5} \mathbf{~}$} & \multicolumn{2}{c|}{$\mathbf{9} \mathbf{m}$} & \multicolumn{2}{c|}{$\mathbf{4 , 5} \mathbf{~ m}$} \\
\cline { 3 - 8 } & & \multicolumn{1}{|c|}{ Inflow } & Outflow & Inflow & \multicolumn{1}{c|}{ Outflow } & \multicolumn{1}{c|}{ Inflow } & \multicolumn{1}{c|}{ Outflow } \\
\hline Nitrit & $\mathrm{mg} / \mathrm{L}$ & 1,12 & 1,09 & 1,13 & 1,24 & 1,14 & 1,16 \\
\hline Nitrat & $\mathrm{mg} / \mathrm{L}$ & 6,67 & 6,24 & 5,66 & 4,61 & 5,63 & 4,23 \\
\hline Fosfat & $\mathrm{mg} / \mathrm{L}$ & 0,38 & 0,35 & 0,56 & 0,51 & 0,59 & 0,56 \\
\hline
\end{tabular}

Kadar nitrit pada penelitian ini terlihat pada Gambar 5 pada pulau apung dengan jarak pengambilan sampel awal dan akhir 13,5 $\mathrm{m}$ efektif menurunkan kadar nitrit. Pada pulau apung dengan jarak $4,5 \mathrm{~m}$ dan $9 \mathrm{~m}$, jumlah nitrit justru meningkat. Hal ini dapat terjadi karena adanya denitrifikasi yaitu reaksi reduksi nitrat menjadi nitrit, nitrit oksida, dan gas nitrogen ${ }^{13)}$.

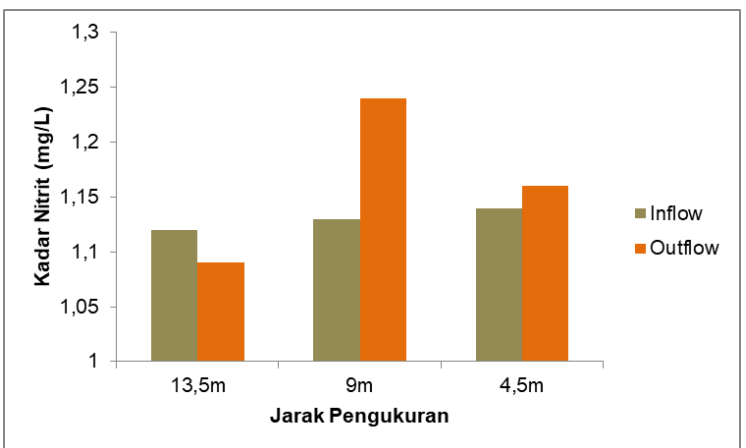

Gambar 5. Kadar Nitrit

Berdasarkan hasil analisis sampel, terjadi penurunan kadar nitrat disetiap jarak pengambilan sampel awal dan akhir pada pulau apung dapat dilihat pada Gambar 6 . Penurunan paling besar terjadi pada pulau apung dengan jarak $9 \mathrm{~m}$. Penurunan terbesar kedua pada pulau apung jarak 4,5 $\mathrm{m}$ dan terakhir pada 13,5 m.

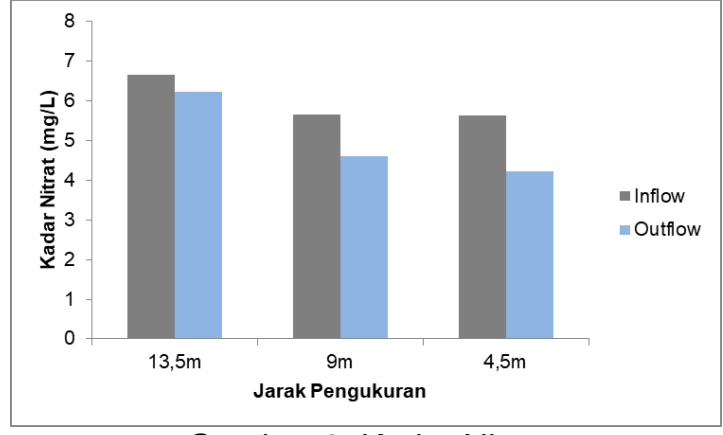

Gambar 6. Kadar Nitrat

Pada Gambar 7 terlihat terjadinya penurunan pada ketiga jarak pengambilan sampel awal dan akhir pulau apung. Kandungan fosfat yang tinggi menyebabkan suburnya alga dan organisme lainnya yang dikenal dengan eutrofikasi. Nilai fosfat yang diperoleh yaitu $0,3 \mathrm{mg} / \mathrm{L}$ hingga $0,6 \mathrm{mg} / \mathrm{L}$ masih dibawah angka maksimum total Fosfat sebagai P pada sungai kelas III yakni $1 \mathrm{mg} / \mathrm{L}$. Persentase penurunan fosfat bernilai kecil karena fosfat sulit diserap oleh tanaman. Fosfat berasal dari deterjen dalam limbah cair dan pestisida serta insektisida dari lahan pertanian. 


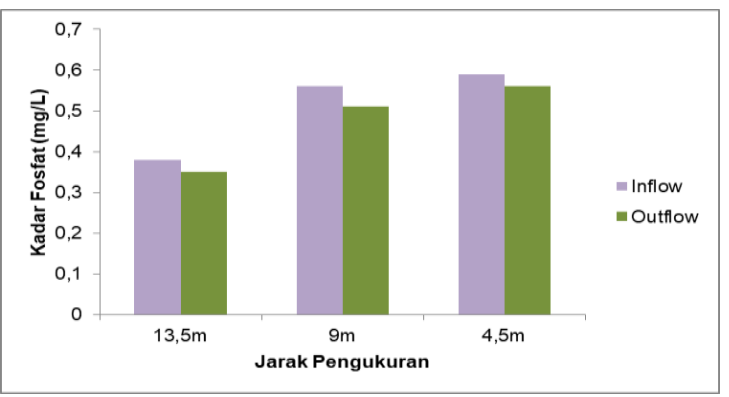

Gambar 7. Kadar Fosfat

Berdasarkan ketiga parameter yang diukur pada ketiga jarak pengambilan sampel awal dan akhir pulau apung, yang mampu menurunkan kadar nitrit, nitrat, maupun fosfat yaitu pulau apung berukuran $13,5 \mathrm{~m}$. Pada jarak pulau apung 4,5 $\mathrm{m}$ dan $9 \mathrm{~m}$ terlihat bahwa justru terjadi peningkatan kadar nitrit. Pada Gambar 8 terlihat bahwa penurunan kadar nitrat optimum pada ukuran pulau apung 9 mmencapai $18 \%$ dan penurunan pada jarak pulau apung 4,5 $\mathrm{m}$ sekitar $16 \%$, sedangkan pada ukuran pulau apung pada 13,5 m hanya sekitar $6 \%$.

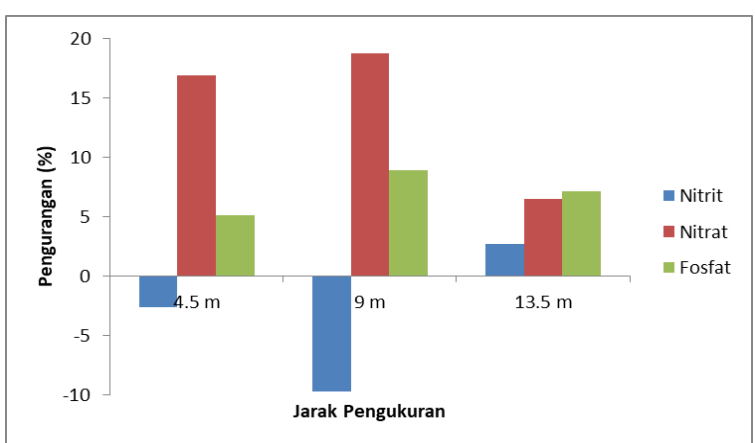

Gambar 8. Persentase Penurunan Kadar Nitrit, Nitrat, dan Fosfat

\section{KESIMPULAN}

Hasil ujicoba pulau apung dengan rumput vetiver dalam upaya penurunan kadar pencemaran air sungai dapat disimpulkan bahwa variasi jarak pengambilan sampel yang dilakukan mampu menurunkan kadar nitrit, nitrat dan fosfat. Penurunan optimum terjadi pada nitrat yang mencapai $18 \%$ dengan jarak pulau apung 9 meter. Tiga ukuran pulau apung yang berbeda cukup efektif untuk menurunkan fosfat.

\section{DAFTAR PUSTAKA}

Herlambang, A. (2006). Pencemaran Air dan Strategi Penanggulangannya. Jurnal Air Indonesia Vol. 2 No. 12006 Hal: 16 - 29.

Agustiningsih, S., Sasongko, S.B., Sudarno. (2012). Analisis Kualitas Air dan Strategi Pengendalian Pencemaran Air Sungai Blukar Kabupaten Kendal. Jurnal Presipitasi, Vol. 9, No. 2, September 2012. ISSN 1907 - 187X

Gazali, I., Widiatmono, B.R., Wirosoedarmo, R. (2013). Evaluasi Dampak Pembuangan Limbah Cair tehadap Kualitas Air Sungai Klinter Kab. Nganjuk. Jurnal Keteknikan Pertanian Tropis dan Biosistem, Vol. 1 No. 2, Juni $2013,1-8$

Reinsel, M. (2014). A New Wetlands Technology for Wastewater Treatment, Floating Islands as a Remediation Tool. Pollution Engineering June 2, 2014

Risamasu, FJL., Prayitno, HB. 2011. Kajian Zat Hara Fosfat, Nitrit, Nitrat dan Silikat di Perairan Kepulauan Matasiri, Kalimantan Selatan. IImu Kelauta, Vol 16(3) 135-142.

Susana, T. 2004. SUMBER POLUTAN NITROGEN DALAM AIR LAUT. Oseana, Volume XXIX, Nomor 3,pp 25 - 33, ISSN 0216-1877.

Nursanto, Jefri. 2016. Analisis Analisis Kapasitas Fitoremediasi Tanaman Vetiver (Chrysopogon Zizanioides) Dalam Mereduksi Limbah Cair Organik Studi Kasus Kerambak Jaring Apung Di Waduk Cirata. Sekolah Pascasarjana, IPB. Bogor.

Purwani, J. 2010. Remediasi Tanah dengan Menggunakan Tanaman Akumulator Logam Berat Akar Wangi (Vetiveria zizaniodes L.). Prosiding Seminar Litbang Pertanian.

http://balittanah.litbang.pertanian.go.id/in d/dokumentasi/prosidingsemnas2010/jati 2.pdf [6 Januari 2015] 
Jeni. 2015. Minimalisasi Pencemaran Sungai Melalui Pengenalan Pemanfaatan Rumput Vetiver Pada Masyarakat Sekitar Bantaran Sungai.

Dodkins, I., Mendzil, A.F., O'Deaa, L. (2014). Enterprise Assist: Floating Treatment Wetlands (FTWs) in Water Treatment: Treatment Efficiency and Potential Benefits of Activated Carbon. Susteinable Expansion of the Applied Coastal and Marine Sectors (SEACAMS) Swansea University, Wales

Kellogg, S. Pettigrew, S. (2008). How to Build a Floating Trash Island, Toolbox for Sustainable City Living: a Do-It-Ourslef Guide. South End Press 2008. http://www.lowtechmagazine.com/how-

to-build-a-floating-trash-island.html [12 Januari 2015]

Priyanto Priyanto, B., Prayitno, J. 2000. Fitoremediasi sebagai Sebuah Teknologi Pemulihan Pencemaran, Khususnya Logam Berat. Prosiding Seminar Nasioanl Peranan Teknologi Lingkungan dalam Pengembangan Industri dan Pengelolaan Sumberdaya Alam yang Berkelanjutan BPPT, Jakarta, 11 - 12 Juli 2000.

Hastuti, Y.P. 2011. Nitrifikasi dan denitrifikasi di tambak. Jurnal Akuakultur Indonesia 10 (1), 89-98. 